\title{
An Electron Microscopic Observation of the Nucleolar Material Attached to the Chromosomes of HeLa Cells in Metaphase
}

\author{
Akiko Terauchi
}

Rcceived August 11, 1973

\begin{abstract}
Summary. A cluster of granules has been known by electron microscopy to occur in contact with the surface of metaphase chromosomes, and is considered to be an altered form of nucleolus in the mitotic phase. In the present examination three types of specimens of HeLa cells, namely, sections stained doubly with uranyl acetate and lead citrate, those stained with EDTA according to the regressive staining method of BERNHARD (1969), and those digested by RNase were compared by electron microscopy in regards to the relationship between the chromosomes and the granules. After the EDTA treatment chromosomes containing DNP were bleached, wheareas the granules maintained their electron density. Futhermore, the latter were digested by RNase, suggesting RNP content. The granules are $150 \AA$ in diameter and resembled the ribosomes. They appear in prophase and are most distinct and abundant in metaphase.
\end{abstract}

In the past ten years it has been clarified by electron microscopists that some nucleolar components were associated with metaphase chromosomes. For instance, material derived from the nucleolus, in other words, a nucleolar remnant which was represented by ribosome-like particles, was attached to metaphase chromosomes in root merismatic cells of Vicia fava (LAFONTAINE and ChouinaRD, 1963), in grasshopper neuroblast cells (Stevens, 1965), in Chinese hamster cells (Hsu et al., 1965; BRINKLEY, 1965; NoEL et al., 1971), in cells of human testis, peripheral blood leukocytes, embryo lung, and bone marrow (HENEEN and Nichols, 1966), and in Indian muntjac cells (Comings and ОкаDA, 1971). On the other hand, some authors reported that the granular element of prenucleolar material was observed better around chromosomes in anaphase and telophase than in metaphase (Yasuzumi and Sugihara, 1965; Sugroka, 1970).

It is often difficult to distinguish, under the electron microscope, nucleolar material from the profile of chromosomes in the ultrathin section prepared by the routine method since they occur too close to each other. In order to avoid this difficulty a convenient method was employed in this study: the electron microscopic regressive staining proposed by BERNHARD (1969) who succeeded in staining preferentially structures containing ribonucleoprotein (RNP) by a combination of classical uranium and lead salt staining and treatment with a chelating agent such as EDTA. After this method, structures containing deoxyribonucleoprotein (DNP) were bleached whereas RNP containing elements maintained their electron density. Some results obtained on the metaphase chromosomes and the nucleolar remnant in HeLa cells using this staining method will be reported in this paper. 


\section{Materials and Methods}

\section{Cell culture}

HeLa S3 cell was used in the present study. The cells were cultured within Hinuma type culture bottles, with Eagle's MEM (Nissan) added to $10 \%$ bovine serum, at a temperature of $37^{\circ} \mathrm{C}$.

In order to collect metaphase cells, the cells were synchronized according to the blocking method using excess thymidine and colcemid according to DoIDA and OKADA (1967), and Nagata (1972). For the following $10 \mathrm{hrs,} \mathrm{the} \mathrm{cells} \mathrm{were} \mathrm{cultured} \mathrm{with}$ Eagle's MEM added containing $2.5 \mathrm{mM} / \mathrm{ml}$ of thymidine, and harvested. Colcemid was added at a final concentration of $0.03 \mu \mathrm{g} / \mathrm{ml}$ for the last $2 \mathrm{hrs}$ befor harvesting.

\section{Electron microscopy}

The cells were removed from the surface of the culture bottle with a rubber policeman when they were growing in logarythmic phase at 24-30 hrs after subculture. Collected cells were centrifuged at $500 \mathrm{rpm}$ for $5 \mathrm{~min}$ and the cell pellets were used for electron microscopy. Three types of specimens were prepared.

\section{Preparation by routine method}

The cells were fixed for $40 \mathrm{~min}$ in $2.5 \%$ glutaraldehyde buffered at $\mathrm{pH} 7.4$ with $0.1 \mathrm{M}$ cacodylate and postfixed for $40 \mathrm{~min}$ in $1 \%$ osmium tetroxide buffered with cacodylate. Fixations were performed at $4^{\circ} \mathrm{C}$. After dehydration in a series of increasing concentrations of ethyl alcohol and embedding in Epon, ultrathin sections were made on an LKB ultrotome with glass knives. The sections were then mounted on formvar and carbon-coated grids and doubly stained with uranyl acetate (WATSON, 1958) and lead citrate (Venable and Coggeshall, 1965).

\section{Preparation by regressive staining with EDTA}

The cells were fixed singly in $2.5 \%$ glutaraldehyde. Dehydration, embedding and sectioning were performed as mentioned above. The sections were stained with uranyl acetate for $5 \mathrm{~min}$ and rinsed with distilled water. The grids adhering the sections were then floated on a $0.2 \mathrm{M}$ EDTA solution ( $\mathrm{pH} 6.3$ with $1 \mathrm{~N} \mathrm{NaOH}$ ) for $5 \mathrm{~min}$ to $2 \mathrm{hrs}$ at room temperature, rinsed again and stained with lead citrate for $30 \mathrm{~min}$.

Fig. 1. An electron micrograph showing the metaphase chromosomes of a HeLa cell associated with the granular cluster. The granules $(G r)$ formed a large cluster and become attached to chromosomes $(\mathrm{Ch})$. The electron density of the granular material is lower than that of chromosomes. Glutaraldehyde and osmium fixation, Epon embedding, and uranyl acetate and lead citrate double staining. $C$ centriol $\times 5,600$

Fig. 2. A kinetochor of the mitotic chromosome. Only few granules are seen attached to chromosomes (arrow). $\times 32,000$

Fig. 3. An interphase cell treated with EDTA. Peri- and inter-chromatin and nuclear membrane associated chromatin are bleached, whereas the nucleolus maintains its general electron density. Fixed in glutaraldehyde, embedded in Epon, prestained with uranyl, treated with $0.2 \mathrm{M}$ EDTA solution for $40 \mathrm{~min}$, and poststained with lead citrate. $\times 5,000$ 


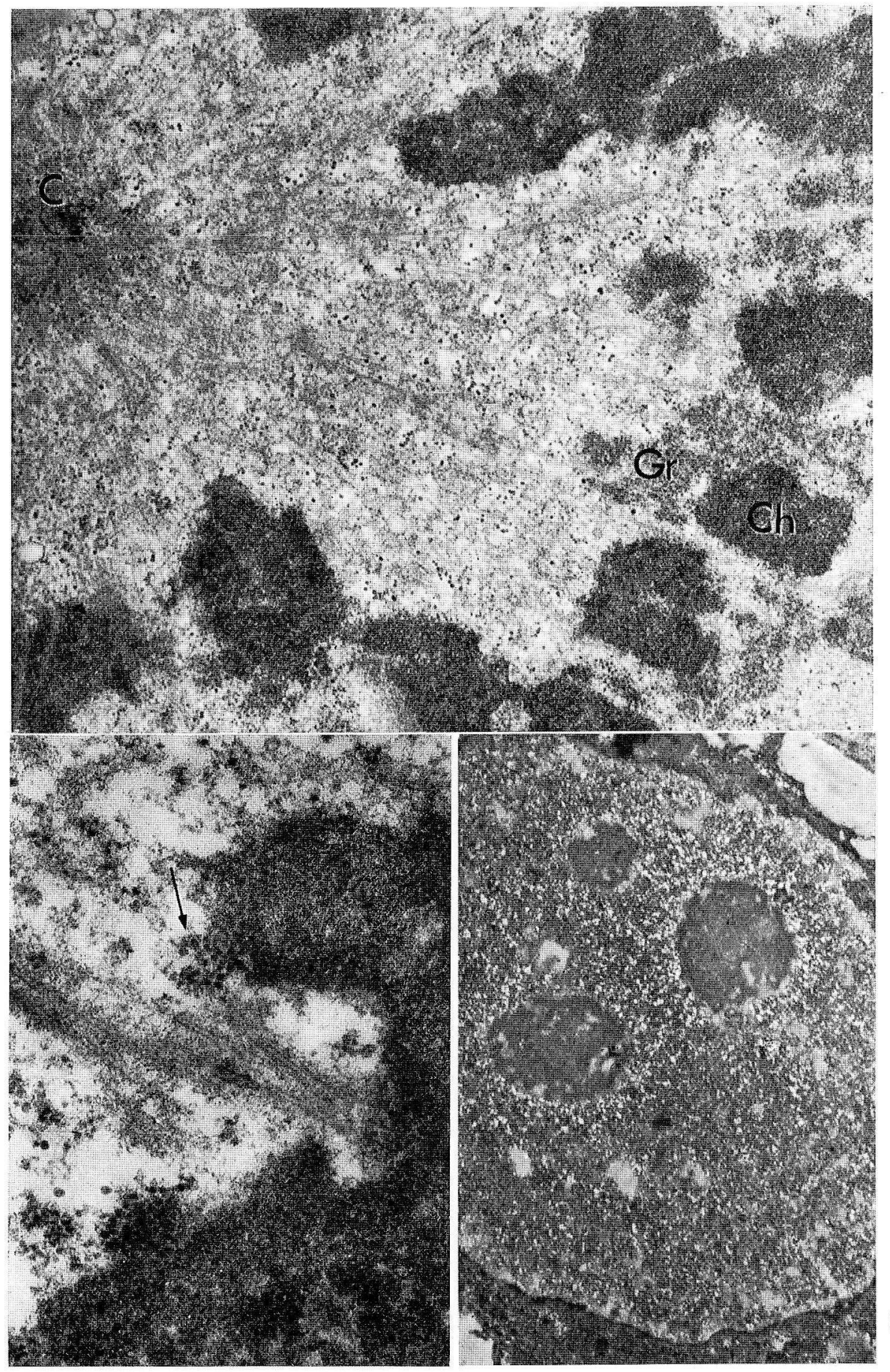




\section{Preparation for enzymatic digestion by RNase}

The cells were fixed singly in $2.5 \%$ glutaraldehyde. Dehydration and embedding in hydroxypropylmethacrylate (HPMA) (Rohm and Haas) were carried out following Leduc and Holt (1965). These ultrathin sections were used for enzymatic digestion, regressive staining with EDTA and routine double staining. The HPMA sections mounted on grids were floated on the surface of a $0.1 \%$ RNase (Worthington Biochem. Corp.) solution in distilled water (BERNHARD, 1969) for $2-4$ hrs at $37^{\circ} \mathrm{C}$ before they were stained with uranyl acetate and lead citrate.

All preparations were examined with transmission electron microscopes, Hitachi HU-11 and HS-8.

\section{Results}

The granules attached to chromosomes in metaphase were observed in electron microscopic preparations prepared by the following three methods.

\section{Preparations by the routine method}

The electron density of the granules was lower than that of the chromosomes (Fig. 1). In many mitotic cells the granules attached to chromosomes in only two or three layers (Fig. 2). Some parts of the chromosomes were not associated with any granular element. Certain chromosomes always lacked granules at the kinetochore as
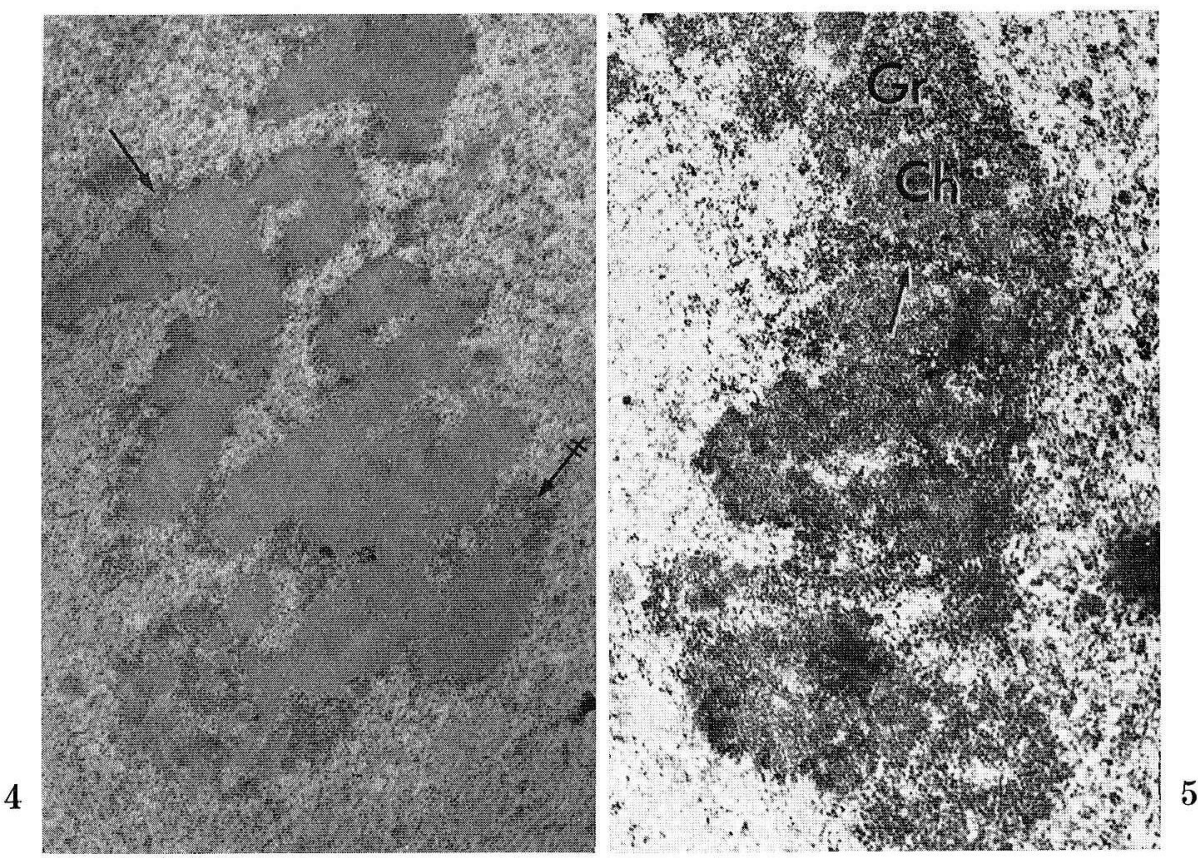

Fig. 4. A metaphase plate treated with EDTA. The granules attached to chromosomes along their long axes (arrow), or at the tops of their arms (arrow with double tails). $\times 12,000$

Fig. 5. A group of chromosomes $(C h)$ in metaphase is buried in a large cluster of granules $(G r)$. A perichromatin granule is shown. Gaps are seen between the chromosomes and the cluster (arrow). Treated with EDTA for $30 \mathrm{~min} . \quad \times 14,000$ 
shown in Figure 2. The granules were uniform in shape and $140-160 \AA$ in diameter.

\section{Preparations by regressive staining}

In the EDTA treated preparation (Fig. 3), the interphase nuclear membrane, the nucleolus associated chromatin, and the clumps of the chromatin dispersed in the nucleoplasm were observed to decrease their electron density, whereas the electron density of nucleolus persisted. In mitotic cells, even after treatment in a $0.2 \mathrm{M}$ EDTA solution for 30-40 min, the fine structure of the mitotic spindle, membrane bounded bodies, rough surface endoplasmic reticulum, mitochondria, ribosomes and microfilaments was well preserved. Chromosomes were bleached, wheareas the granular elements attached to chromosomes maintained their electron density. Consequently, it was surmised that they contained RNP and were originated from the nucleolus. The granules were attached to various parts of the chromosomes. For instance, they were attached along the long axis of the chromosome or the top of its arm (Fig. 4), or the whole group of chromosomes was buried in a large cluster of granules (Fig. 5).

No granules were found around the chromatin in the stage of interphase. Granules identical with those in metaphase occurred in prophase. The cell shown in Figure 6 apparently was in prophase because of dissociation and undulation of the nuclear membrane (RobBins and Goantas, 1964; Murray et al., 1965). The nucleolus still persisted and granules were seen around the surface of chromosomes which were
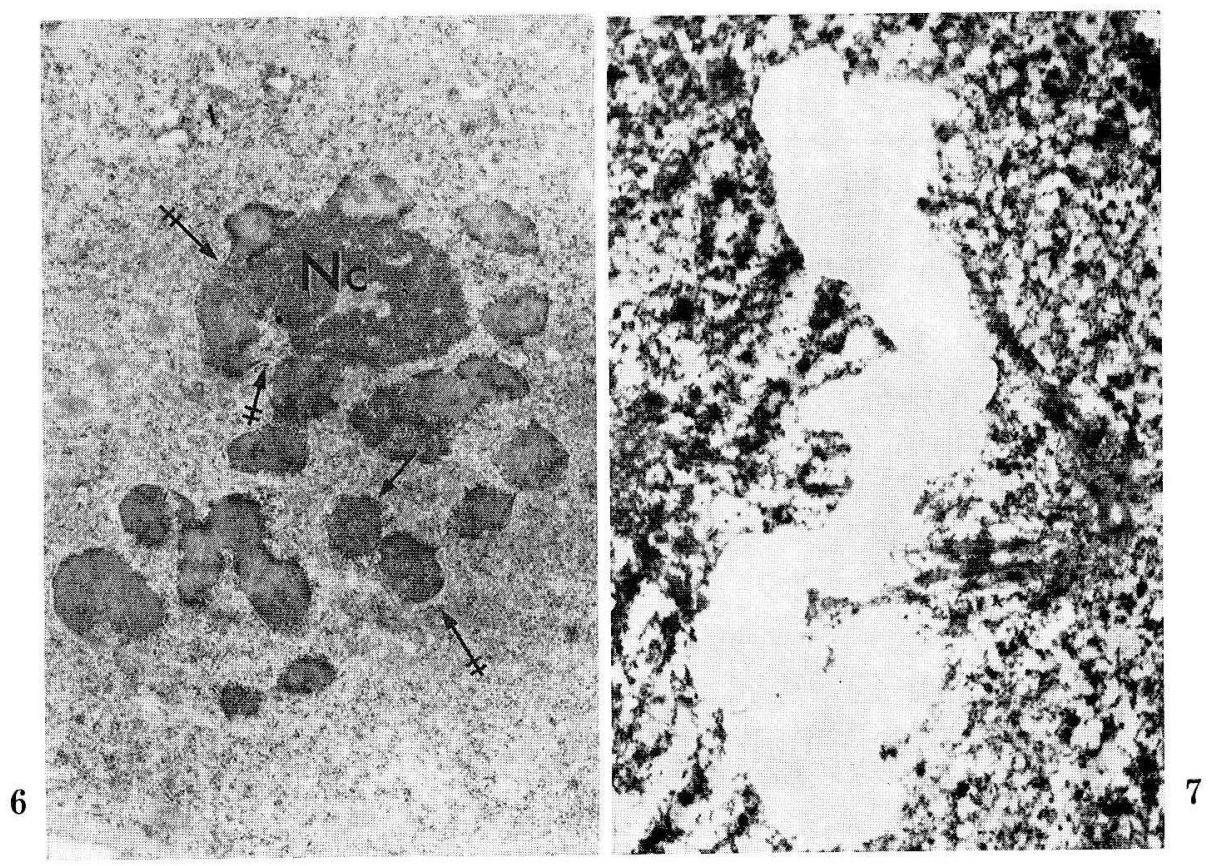

Fig. 6. A prophase cell treated with EDTA. The granular material is already seen in this stage (arrow). Nc nucleolus, arrows with double tails: nuclear membrane. $\times 7,000$

Fig. 7. A metaphase plate affected extremely by EDTA treatment for 2 hrs. $\times 14,000$ 
condensed along the nuclear membrane. In metaphase the granules were most abundant and distinct.

According to BERNHARD (1969), the effect of EDTA treatment on the stainability of cell components depends on fixatives, embedding media, age of blocks, thickness of the section, staining time, and concentration of EDTA solution. In the present examination, the best treating time with $0.2 \mathrm{M}$ EDTA was $30-40 \mathrm{~min}$ at room temperature for the sections fixed singly in glutaraldehyde, embedded in Epon and cut $600-900 \AA$ thick. When a section was treated for more than 2 hrs not only the granules but also the chromosomes were markedly affected (Fig. 7). The effect of EDTA was the same on fresh and aged blocks; the same result was obtained from the specimens cut immediately after polymerization and also after two months. A suitable treating time for the section from the HPMA-embedded block was 10-20 min at room temperature.

The electron density of chromosomes or chromatin, which had been decreased by EDTA treatment, was recovered by uranyl staining. A decrease in the general electron density of chromosomes occurred when the section was stained previously with uranyl acetate, but it did not occur when the section was stained previously with lead citrate for $5 \mathrm{~min}$.

\section{Enzymatic digestion by RNase}

Sections embedded in HPMA were digested by RNase for the purpose of surmising the chemical components of the granules in question. In interphase cells, the electron density of the nucleolus was decreased by digestion. A homogenous material, which was stained faintly by uranium acetate and lead citrate, was recognized surrounding chromosomes in metaphase. The fine constitution of the material was not clear in this electron micrograph (Fig. 8). The material is believed to correspond to the granules because of its localization.

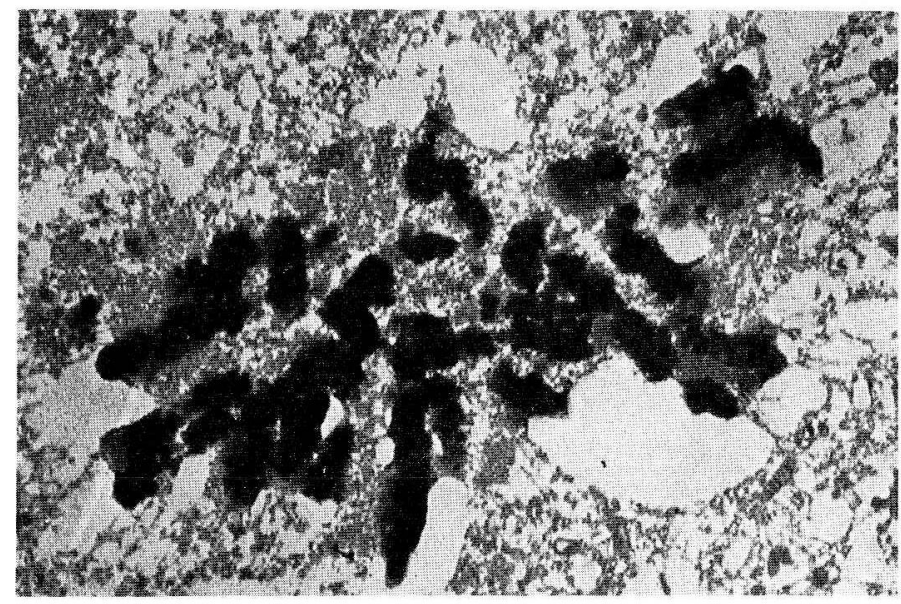

Fig. 8. A metaphase plate digested by RNase. Faintly stained materials surround the chromosomes. Fixed with glutaraldehyde, embedded in .HPMA, digested by $0.1 \%$ solution of RNase for $3 \mathrm{hrs}$ at $37^{\circ} \mathrm{C}$, and stained by uranyl acetate and lead citrate. $\times 14,000$ 


\section{Discussion}

In the present study granular material associated with chromosomes in metaphase was observed by electron microscopy. The granules were considered to be originated from a nucleolus since it was shown to contain RNP by the result of EDTA treatment and digestion with RNase in the present examination. Some investigators reported that a material was attached to chromosomes through mitotic phases (LAfontaine and Choinard 1963; Stevens, 1965; Hsu et al., 1965; Brinkley, 1965; Yasuzumi and Sugihara, 1965; Heneen et al., 1966; Noel et al., 1971; Comings et al., 1971). This material was regarded as the nucleolar remnant since it was similar to ribosomes in size and electron density (Yasuzumi and Sugihara, 1965; Stevens, 1965); furthermore, the material incorporated a labeled precoursor of ribonucleic acid, tritiated uridine, and stained red with pyronin according to a light microscopic histochemical staining (Hsu et al., 1965). The nucleolar remnant adhered to the surface of the chromosomes (Lafontaine and Chouinard, 1963; Stevens, 1965; Yasuzumi and SugIHARA, 1965; BRINKLEY, 1965) and at some portions the processes starting from chromosomes and coming to be associated with the nucleolar remnant were observed (LAfontaine and Chouinard, 1963; Stevens, 1965). In the present observations the author could not gain any sufficient result as regards the structure of the attachment between the two elements.

BERNHARD and his associates developed a new electron microscopic regressive staining method using a chelating agent, EDTA (BERnhARD, 1969; Monneron and Bernhard, 1969; Petrov and Bernhard, 1971). With this staining, a cell structure containing DNA is decreased in electron density, whereas RNP maintains its contrast. The fine mechanism of this peculiar action of EDTA on electron microscopic staining remains obscure. A chelating agent, EDTA, combines with uranium to form a soluble complex, which is removed from tissue. EDTA reacts to uranium, which is combined with DNP, as well as to uranium which is combined with RNP, the action of EDTA appearing earlier on the former than on the latter. When the EDTA treatment is continued for only a short time, the components containing DNP as chromatin are bleached. After long treatment the nucleolus which contains RNP is more affected, too (Fig. 8). The specificity of the EDTA staining is only relative and structures such as glycogen, secretory granules, lysosome, and collagenous fibers are also affected by EDTA (НАYA, 1970$)$. In the present examination, when a section was stained with lead citrate before EDTA treatment, neither chromatin nor the nucleolus was bleached. It is necessary to examine the action of EDTA on other heavy metals which are used for electron microscopic staining.

Acknowledgment. The author wishes to express her thanks to Associate Prof. T. Nagata and Mr. S. Yokota for their reviewing the manuscript, and to Dr. T. NAwA in the First Department of Anatomy for his guidance during the course of the present study. 


\title{
HeLa 細胞の分裂中期染色体に附着している核小体成分の 電子顕微鏡による観察
}

\author{
寺 内 昭 子
}

有系分裂中期の染色体の表面にリボゾーム様の顆粒の集塊が附着しているのが しばし ぼ電顕標本で観察される。この顆粒成分は今日までの報告から 核小体が分裂期に示す一 形態であろうと推察されている. 今回の報告ではウランと鉛による二重染色, BERNHARD （1969）によるEDTA を用いた電顕的退後染色，RNase による消化の三種の標本を電 顕で比較観察し，染色体と顆粒成分の関係について述べた. EDTA 処理によりデオキシ リボ核蛋白を含む染色体の電子密度は低下し，顆粒成分の電子密度は低下しなかったの で，両者のコントラストの差が開いた結果，顆粒成分の全体的な分布の観察に良い結果 を得た.さらにこの顆粒成分は RNase で消化された．顆粒は直径 $150 \AA$ でありリボ ゾームに似ている．静止核のクロマチンの周囲には認められず，分裂前期に現われ，中 期に最も多量にかつ明瞭に染色体周囲に認められた。

\section{References}

Bernhard, W.: A new staining procedure for electron microscopical cytology. J. Ultrastr. Res. 27: 250-265 (1969).

Brinkley, B. R.: The fine structure of the nucleolus in mitotic divisions of Chinese hamster cells in vitro. J. Cell Biol. 27: 411-422 (1965).

Comings, D. E. and T. A. Okada: Fine structure of kinetochore in Indian muntjac. Exp. Cell Res. 67: 97-110 (1971).

Doida, Y. and S. Okada: Synchronization of L5178Y cells ly successive treatment with excess thymidine and colcemid. Exp. Cell Res. 48: 540-548 (1967).

Hayat, M. A.: Principles and techniques of electron microscopy. Vol. I, New York, Van Nostrand Reinhold Company, 1970.

Heneen, W. K. and W. W. Nichols: Persistence of nucleoli in short term and long term cell cultures and in direct bone marrow preparations in mammalian materials. J. Cell Biol. 31: 543-561 (1966).

Hsu, T., F. Arrighi, R. Klevecz and B. Brinkley: The nucleoli in mitotic divisions of mammalian cells in vitro. J. Cell Biol. 26: 539-553 (1965).

Lafontaine, J. G. and L. A. Chouinard: A correlated light and electron microscope study of the nucleolar material during mitosis in Vicia faba. J. Cell Biol. 17: 167-201 (1963).

Leduc, E. H. and S. J. Holt: Hydroxypropyl methacrylate, a new water-miscible embedding medium for electron microscopy. J. Cell Biol. 26: 137-156 (1965).

Monneron, A. and W. Bernhard: Fine structural organization of the interphase in some mammalian cells. J. Ultrastr. Res. 27: 266-288 (1969).

Murray, R. G., A. S. Murray and A. Pizzo: The fine structure of mitosis in rat thymic lymphocytes. J. Cell Biol. 26: 601-619 (1965).

Nagata, T.: Radioautographic study on intramitochondrial nucleic acid synthesis: Its relationship to the cell cycle in cultivated cells. Proc. 4th Int. Congr. Histochem. Cytochem. 223-224 (1972).

Noel, J. S., W. C. Dewey, J. H. Abel, Jr. and R. P. Thompson: Ultrastructure of the nucleolus during the Chinese hamster cell cycle. J. Cell Biol. 49: 830-847 (1971). 
Petrov, $\mathbf{P}$. and W. Bernhard: Experimentally induced changes of extranucleolar ribonucleoprotein components of the interphase nucleus. J. Ultrastr. Res. 35: 386-402 (1971).

Robbins, E. and N. K. Goantas: The ultrastructure of a mammalian cell during the mitotic cycle. J. Cell Biol. 21: 429-463 (1964).

Stevens, B. J.: The fine structure of the nucleolus during mitosis in the grasshopper neuroblast cell. J. Cell Biol. 24: 349-368 (1965).

Sugioka, T.: Electron microscope studies on the fine structure of chromosomes. J. Nara Med. Ass. 21: 179-190 (1970).

Venable, J. H. and R. Coggeshall: A simplified lead citrate stain for use in electron microscopy. J. Cell Biol. 25: 407-408 (1965).

Watson, M. L.: Staining of tissue sections for electron microscopy with heavy metals. J. biophys. biochem. Cytol. 4: 475-478 (1958).

Yasuzumi, G. and R. Sugihara: The fine structure of nuclei as revealed by electron microscopy. II. The process of nucleolus reconstitution in Ehrlich ascites tumor cell nuclei.: Exp. Cell Res. 40: 45-55 (1965).

寺内昭子

事390 松本市旭 3-1-1

信州大学医学部

小児科学教室
Dr. Akiko Terauchi

Department of Pediatrics

Shinshu University School of Medicine

Asahi 3-1-1, Matsumoto, 390 Japan 